\title{
Household Energy Demand and Its Impact on the Ecological Capital of Nech Sar National Park, Ethiopia
}

\author{
Molla Mekonnen Alemu \\ University of Leicester, Leicester, UK \\ Email: mollamekonnen@gmail.com
}

How to cite this paper: Alemu, M.M. (2016) Household Energy Demand and Its Impact on the Ecological Capital of Nech Sar National Park, Ethiopia. Journal of Environmental Protection, 7, 1273-1282. http://dx.doi.org/10.4236/jep.2016.710112

Received: August 8, 2016

Accepted: September 10, 2016

Published: September 13, 2016

Copyright $\odot 2016$ by authors and Scientific Research Publishing Inc. This work is licensed under the Creative Commons Attribution International License (CC BY 4.0).

http://creativecommons.org/licenses/by/4.0/

(c) () Open Access

\begin{abstract}
Household energy demand is among the prime problems that cause deforestation. The use of fuel wood in the developing countries of Africa, Asia and Latin America is believed to play a key role for the razing of forests and the degradation of associated biodiversity and other land resources. High population growth, increased energy demand, urbanization, infrastructure development, etc. are among the factors that exacerbate the current rate of deforestation in Ethiopia. This growing demand is also posing a threat to the remaining natural capital and associated wildlife of the country's national parks. Nech Sar national park, a jewel in the Rift Valley of Ethiopia is not in different to this threat. The issue is calling for an urgent interference in the provision of environment friendly energy sources, afforestation programmes, raising the level of awareness on climate change, etc. This study is therefore, aimed at exploring the level of household energy demand interference on the woody vegetation of Nech Sar Park and promoting the use of environment friendly and energy saving technologies in the vicinity of the park area and beyond.
\end{abstract}

\section{Keywords}

Energy, Natural Capital, Park, Household

\section{Introduction}

The use of fuel wood as a source of household energy supply is believed to be the primary cause of deforestation in the developing countries of Africa, Asia and the Latin America. This has in turn caused a sever degradation to the environment and land resources productivity [1].

The predominant source of energy in Ethiopia is biomass energy and accounts about 
94\%. Fuel wood, charcoal, and dung are among the prime traditional energy sources in the country [2].

The rural population is entirely dependent on biomass for its day to day energy demand, with the exception of the need for getting light. It is also unfortunate that, the traditional cooking system involves a huge loss of energy that could have been used otherwise. In addition to this, the traditional system is considered as it is having a magnificent effect on natural resources wastage and degradation, dangerous health risks and negative economic consequences [3].

The strong reliance on fuel wood from forest resources is resulting detrimental ecological threat and a decrease in the agricultural productivity and production systems. Concurrent drought, shortage of rain, etc. are among the challenges which the country is facing. As fire wood collection is primarily considered as a women activity, the increased scarcity and high cost of fuel wood is mainly adding extra burden on the life of women and children.

During the last fifty years, charcoal production increased from a million tonnes to more than three million tonnes per annum. During the same period, fuelwood consumption also increased from forty million to one hundred million cubic meters per annum [4].

Conceivably the most central issue is, however, the bond among household energy use in Ethiopia and its relation with the degradation of the environment-both at the local and the global perspective-and the issue of securing energy. Though the country has a considerable energy potential from solar, wind and animate sources of energy, the threat is posing a severe challenge on the survival of the remaining forest resources of national parks including Nech Sar.

\subsection{Impact of Traditional Energy Utilization System}

The developing regions traditional system of energy utilization is posing a threat to the natural capital, environment, development, health related issues, local land use to global climate change challenges, etc. which is caused by the shortage of environment friendly and affordable sources of energy.

With the current trend of fuel wood consumption, it is estimated that, many of the developing countries will face severe shortage of fuel wood by the year 2025 .

In general, if the current depletion of trees continues, it will lead to the degradation of biodiversity, climate change, sedimentation, desertification and other hazardous things in the environment [3].

Currently, Ethiopia is constructing the Grand Renaissance Dam, the biggest ever on the African continent, up on expected to generate 6000 megawatts. The country is also working on the generation of 1000 megawatts from a geothermal plant. Apart from this, Ethiopia has Africa's largest wind farm that is currently generating 120 megawatts. Ethiopia is looking "at energy as an export sector the way you export gold", notes Donald Kaberuka, head of the AfDB [5].

According to CIA [6], Ethiopia also has 24.92 billion cu m proved natural gas and 
430,000 bbl crude oil proved reserves.

Araya and Yissehak, (2012) mentioned as the potential for oil production from inedible plants such as Jathropa, Castor, and Rapeseed, which can be grown on marginal lands not suitable for agriculture, is also high. They also mentioned oil that can be obtained from Moringa seeds, which is easily found in abundance in the southern part of Ethiopia, could also be used as a source of fuel for household level. Thus, if these renewable and non-renewable energy sources are developed in a sustainable way, it will have a profound impact on environmental development, deforestation as well as economic growth and development.

\subsection{Energy Demand and the Status of Forests in Ethiopia}

In the early 1950 s about $16 \%$ of the total land mass was covered by forests, this percentage has been reduced to less than $3.8 \%$ in the early 1980 s and only $2.7 \%$ or less since 1989 [7] [8]. Population growth, recent increase in infrastructural developments, increased energy demand, forest fire, etc. are among the prominent factors that accelerated the rate of deforestation in the country which in turn caused the extinction of indigenous plant and wild animals [9].

These days the remaining amount has further dropped down due to the ever increasing rate of population which depends on forest resources for fuel wood, construction materials and other associated uses [10], causing a severe degradation to the ecology as well as socio-economic benefits [11]. Apart from this as indicated by Ensermu et al. (1992) cited in Kindeya [9] the country has a total of 120 threatened endemic plant species. Even in those areas which are officially declared to conserve nature and maintain ecosystem services, many of the developing countries including Ethiopia lack sufficient budget and capacity to manage and conserve the resources. As a result of this, many of the valuable land resources which have got regional and global ecological importance are being destroyed from the face of the earth as they are not being valued for their role as nature's genetic reservoirs of the world's biological resources.

\section{Objectives}

The objective of this paper is to assess the impact of Nech Sar National Park vicinity and its surrounding inhabitants energy demand on the ecological capital of the park; suggest alternative energy sources and inform energy policies and strategies which can help to reduce the reliance on the ecological capital of the national parks.

\section{Methodology}

\subsection{Description of the Study Area}

Nech Sar National Park is in Africa's Great Rift Valley, $510 \mathrm{Km} \cdot \mathrm{s}$ southwest of Addis Ababa, Ethiopia. The park is located in the immediate east of Arba Minch city, in the Southern Nations, Nationalities, and Peoples Region, Ethiopia (Figure 1).

Nech Sar National Park's greatest asset is its diverse combination of ground-waterforest, savanna acacia forest, open savanna, escarpment walls, highland acacia forest, 


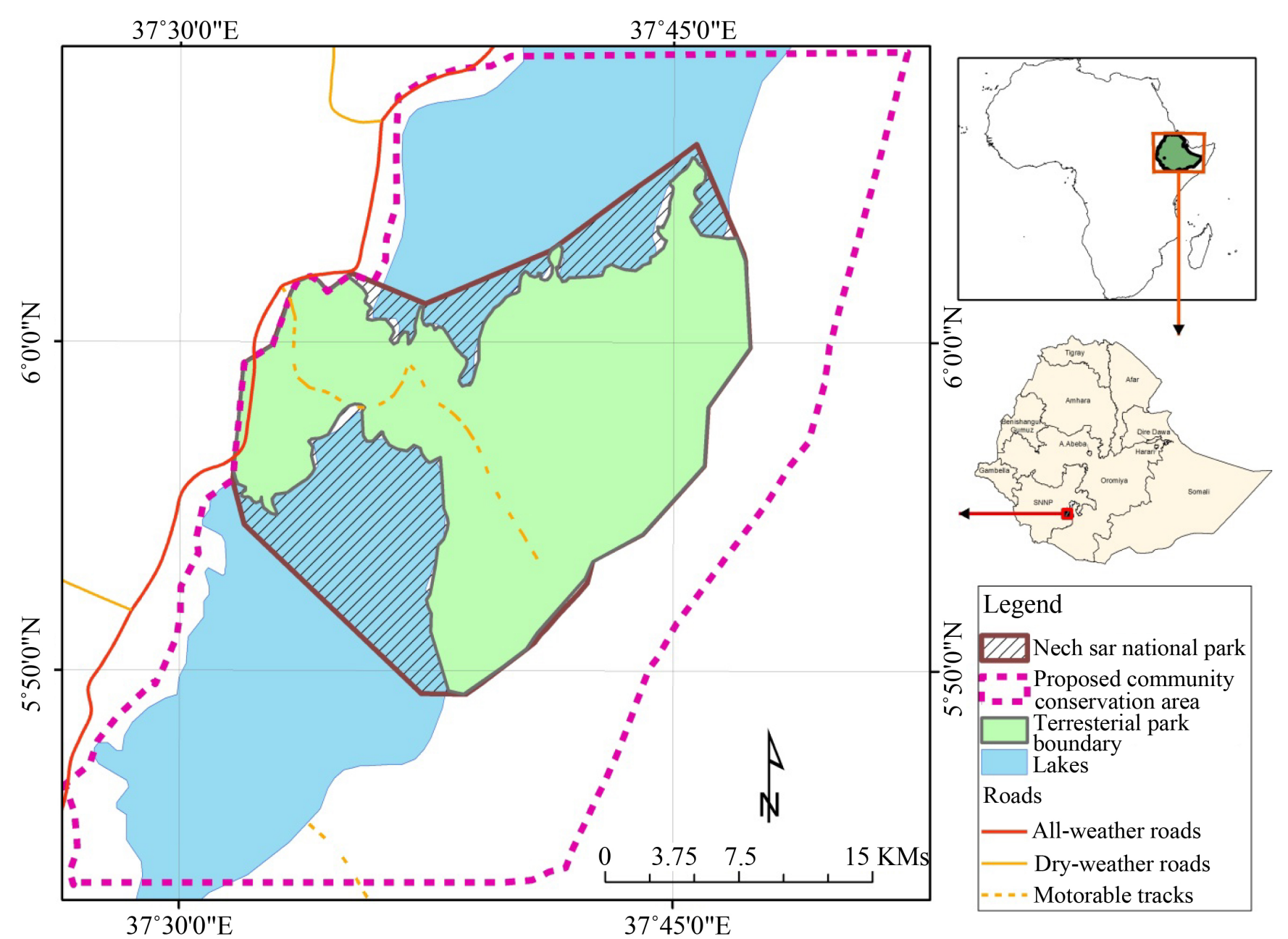

Figure 1. Location of the study area, Nech Sar National Park [14].

hot springs and lakeshores. Nech Sar's ecosystems provide habitats for the world's largest population of the endemic Swayne's hartebeest. The total area of the park is 514 square kilometers with elevations range between 1108 and 1650 meters above sea level. The park was gazetted in 1974 [12]. Nech Sar National Park, a jewel in the crown of Ethiopia's National Parks, is also valued for its physical beauty, endemic species, and diversity ranging from rift valley lakes (Abaya and Chamo) to mountains [13].

\subsection{Data Collection and Analysis}

Semi-structured interviews were used to solicit information from the local inhabitants, staff of the park, park rangers, and other stakeholders on the different factors that are causing the degradation of the natural capital of the park. Secondary data from the park management office and other relevant government offices was also collected. A total of 74 community members ( 42 women) and 11 government staff participated in the interview process.

In order to assess the impact of household energy demand human interference on the woody vegetation of Nech Sar National Park a total of 27 experimental plots mea- 
suring $20 \mathrm{~m} \times 20 \mathrm{~m}$ were laid out randomly along 4 transects which were laid systematically so as to capture the level of human interference on the density of trees in the ground water vegetation on the park (Figure 2). 3 additional plots were also laid out at about 100 - 400 meters from the main office of the park. Based on the level of human interference the plots were categorized under high, less and protected land management types. Protected land management is the area of the park that falls under close supervision of the park management as a result of its location to the park's main office and the area is believed to be undisturbed by human interference. Less human interference is part of the park with a bit of human interference, not very far from the main office of the park whereby fuel wood cutting and livestock grazing can be practiced sometimes; and high human interference is part of the park which is under high human interference as a result of fuel wood collection, charcoal making and livestock grazing activities can be seen very easily. Then data was analyzed by making use of descriptive statistics on excel and SAS.

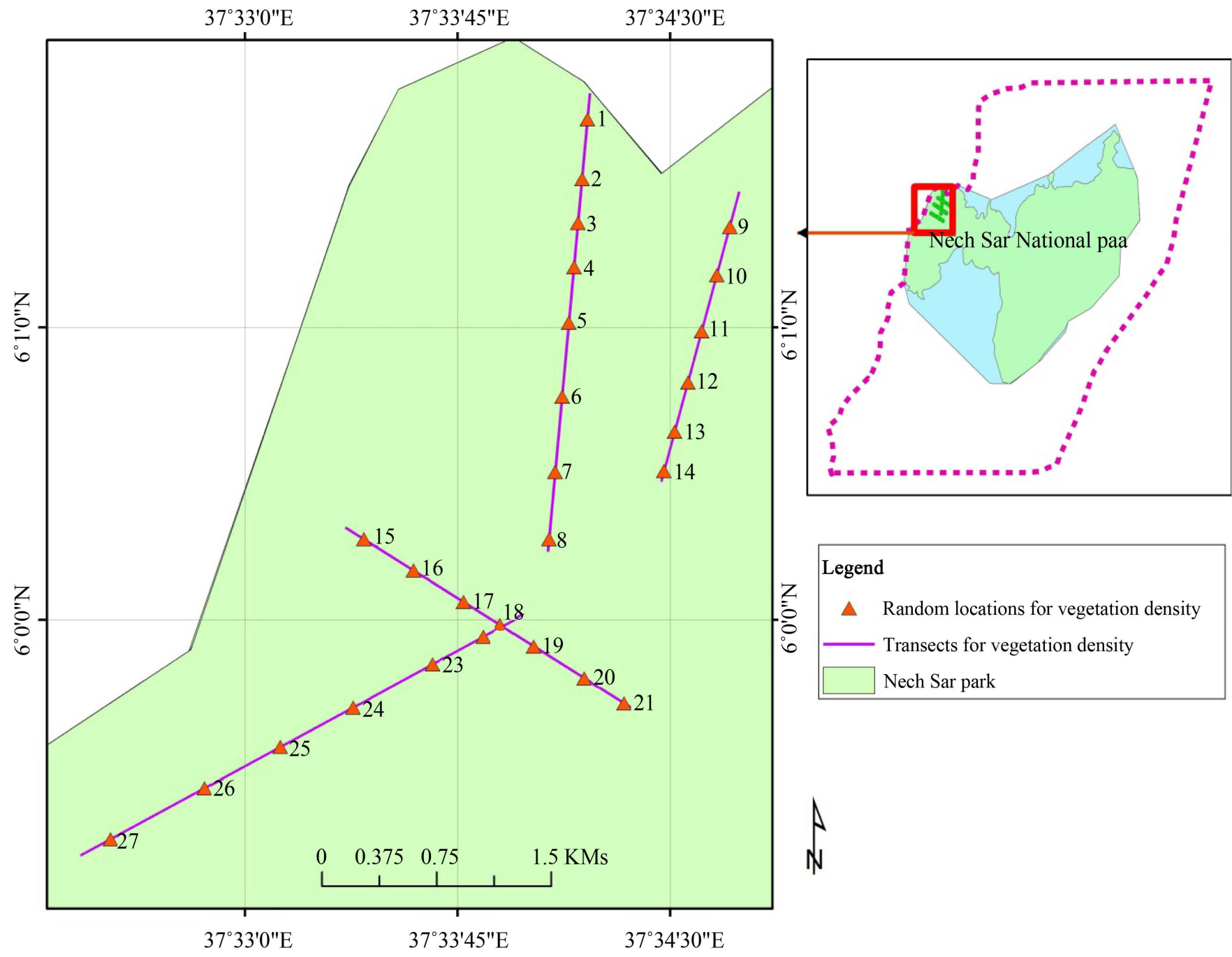

Figure 2. Transects lines along with corresponding experimental plots. 


\section{Result and Discussion}

\subsection{Sources of Household Energy}

Arba Minch town shares an immediate boarder of about $15 \mathrm{~km}$ with Nech Sar National Park. The urban, peri-urban and rural communities are highly dependent on forest resources for construction as well as to meet their household energy demand. Fuel wood collection is also being considered as the major source of livelihood for many inhabitants of the city. People from neighboring districts are also believed to come to Arba Minch city to be engaged in fuel wood collection as a source of additional income generation and means of livelihood. It is estimated $98 \%$ of the household energy source for Arba Minch town dwellers is obtained from fuel wood which largely comes from the forest of Nech Sar National Park [15].

According to the findings of the study and related literature, the main use of energy at the household level is for cooking and lighting. Fuel wood is the predominant source of energy for cooking followed by charcoal. A very meager amount of respondents only used kerosene for very light cooking purposes like making tea and for warming food items (Figure 3). Electricity is mainly used for lighting and some other household items like television and charging mobile phones.

\subsection{Traditional Energy Utilization and Efficiency}

The natural forests are being cleared to meet the ever increasing energy demand of households. Household energy sources and its utilization in least developed countries like Ethiopia, Sierra Leone, etc. is posing a major environmental challenge along with health related problems. As a result of deforestation, natural resources are being degraded which in turn causes for the frequent occurrence of disasters like drought, flooding, landslide, etc. The traditional stoves and kitchens are not efficient in using the

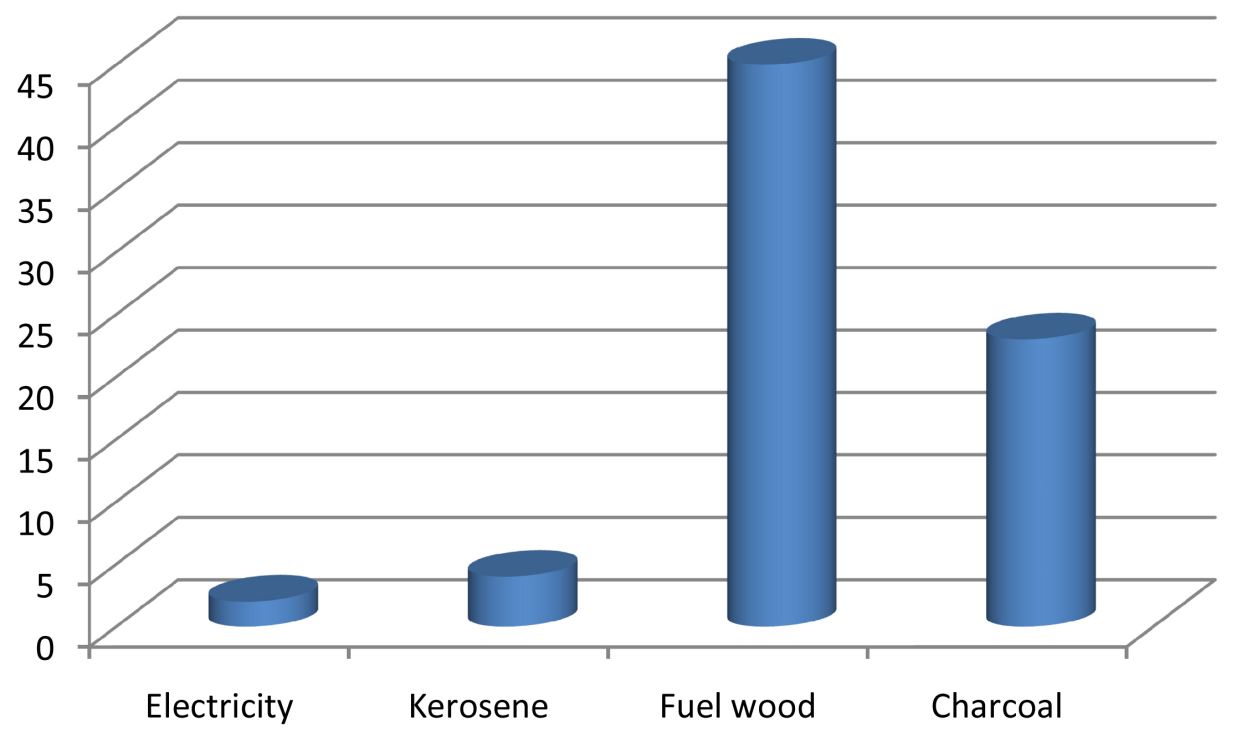

Figure 3. Major sources of energy as expressed by the respondents. 
generated energy in an efficient way. Energy will always be wasted as a result of the openings between the stoves and the cooking utensils. The smoky kitchens are also affecting the breathing system and by causing eye diseases for women who are believed to be the primary caregivers of a household. As a result of the flame which comes out of the open stoves, it is also not uncommon to find a scare on the front side of the lower legs of many women.

Based on the findings of the study, none of the respondents of the survey are making use of solar energy for cooking with the exception of using solar charged torch lights.

Though all woody plants can be used as a source of fuel wood, Table 1 and Table 2 shows as there is still a preference on some tree species to be used as a source of fuel which is based on the amount of fuel energy which can be generated from it, as some tree species may not yield the required amount of energy in a timely fashion.

Unlike charcoal, there is a steady supply of fuel wood in the markets of Arba Minch and the price of the fuel wood also varies based on the quality of the wood. The availability of charcoal usually fluctuates as the law enforcing bodies are trying to control charcoal making and marketing. The weighted average price of the fuel wood and charcoal is summarized in Table 3.

\subsection{Density of Woody Vegetation}

Based on physical observation and findings of the analysis on the density of trees in the ground water vegetation of Nech Sar National Park, it is possible to say that, the park is under immense human impact as a result of the dire need for household energy supply.

Table 1. Type of trees preferred for fuel wood.

\begin{tabular}{ccc}
\hline S.N & Scientific Name & Local Name \\
\hline 1 & Lonchocarpus laxiflorus & Hasso \\
2 & Prunus africanus & Tikur Enchet \\
3 & Acacia polycanta & Deleme \\
4 & Rhus natalensis & Ango Fire \\
\hline
\end{tabular}

Table 2. Type of trees used for charcoal making.

\begin{tabular}{ccc}
\hline S.N & Scientific Name & Local Name \\
\hline 1 & Lonchocarpus laxiflorus & Hasso \\
2 & Prunus africanus & Tikur Enchet \\
3 & Balanites aegyptiaca & Bedeno \\
\hline
\end{tabular}

Table 3. Average cost of fuel wood and charcoal at Arba Minch city.

\begin{tabular}{cccc}
\hline S.N & Type & Cost $/$ Kg/Ethiopian Birr & Cost $/ \mathrm{Kg} / \mathrm{USD}^{*}$ \\
\hline 1 & Fuel wood & 2.00 & 0.09 \\
2 & Charcoal & 4.00 & 0.18 \\
\hline
\end{tabular}

${ }^{\star}$ Exchange rate of $\$ 1$ to 21.87 Ethiopian Birr on July 28, 2016. 
The density of matured trees in the park was found to be dense in the protected land management areas of the park while the less and high human interference management types exhibited a very less density of trees. In 3 of the plots which have fallen under the high human interference part of the park, there were zero matured trees as well as saplings. The highest number of trees per plot was observed in the protected area of the vegetation which goes up to 213 trees per hectare and the lowest number of trees (79) was observed in the high human interference areas of the park (Table 4).

The one way ANOVA (Tables 5-7) also showed as human interference is having a significant effect on the density of trees, saplings and seedlings across the different land management types of the park $(\mathrm{P}<0.05)$.

Table 4. The MEANS procedure for the human interference levels of the park.

\begin{tabular}{ccccccc}
\hline Interference & Obs. & Variable & Label & N & Mean & Std. Error \\
\hline H & 13 & Nsha & Nsha & 13 & 511.54 & 160.49 \\
& & Nsapha & Nsapha & 13 & 667.31 & 168.17 \\
& & Ntreeha & Ntreeha & 13 & 79.81 & 16.48 \\
L & Nsha & Nsha & 8 & 2568.75 & 759.84 \\
& \multirow{2}{*}{9} & Nsapha & Nsapha & 8 & 1728.13 & 284.47 \\
& & Ntreeha & Ntreeha & 8 & 122.81 & 18.59 \\
P & Nsha & Nsha & 9 & 2869.44 & 903.83 \\
& \multirow{2}{*}{9} & Nsapha & Nsapha & 9 & 1538.89 & 242.75 \\
& & Ntreeha & Ntreeha & 9 & 213.33 & 22.39 \\
\hline
\end{tabular}

N.B: Nsha-number of seedlings/ha; Nsapha—number of saplings/ha; Ntreeha-number of trees/ha; Interference$\mathrm{H}$ (high human interference), L (low human interference), P (protected).

Table 5. ANOVA for density of seedlings.

\begin{tabular}{cccccc}
\hline Source & DF & SS & Mean Square & F Value & $\operatorname{Pr}>$ F \\
\hline Model & 2 & $36,571,258.5$ & $18,285,629.3$ & 5.19 & 0.0124 \\
Error & 27 & $95,168,929.0$ & $3,524,775.1$ & & \\
Corrected & 29 & $131,740,187.5$ & & & \\
Total & & & & \\
\hline
\end{tabular}

Table 6. ANOVA for density of saplings.

\begin{tabular}{cccccc}
\hline Source & DF & SS & Mean Square & F Value & $\operatorname{Pr}>$ F \\
\hline Model & 2 & $6,949,750.13$ & $3,474,875.07$ & 7.12 & 0.0033 \\
Error & 27 & $13,186,166.53$ & $488,376.54$ & & \\
Corrected Total & 29 & $20,135,916.67$ & & & \\
\hline
\end{tabular}

Table 7. ANOVA for density of trees.

\begin{tabular}{cccccc}
\hline Source & DF & SS & Mean Square & F Value & $\operatorname{Pr}>$ F \\
\hline Model & 2 & $95,610.4287$ & $47,805.2143$ & 13.19 & 0.0001 \\
Error & 27 & $97,873.7380$ & 3624.9533 & & \\
Corrected Total & 29 & 193484.1667 & & & \\
\hline
\end{tabular}




\section{Conclusions}

Fuel wood and charcoal are the predominant household energy sources for Arba Minch and other neighboring towns. Many people are also reliant on the fuel wood collection and charcoal making as the main stay of livelihoods. The natural vegetation of Nech Sar National Park is being challenged by the ever increasing energy demand of the inhabitants of the area. The study showed that, human interference is affecting the density of the vegetation. The traditional way of utilizing fuel wood is also contributing for the inefficient use of the available resources. If continued in the present trend, the park will no more be able to provide the natural ecosystem services.

The various challenges associated with fuelwood and charcoal would require an urgent action which can amalgamate policies that border on the efficiency of energy use, conservation of energy and a laying the foundation to switch in to modern forms of energy in certain cases.

Apart from these, as the area has a tropical climate which is conducive for the generation of solar energy in a sustainable manner, hence development partners have to put hands together in the generation of alternative energy sources so as to save the precious ground water and riverine vegetation of Nech Sar National Park.

Therefore, conservation and maintenance of the remaining vegetation cover of the park from deforestation are some of the vital issues that need to be addressed by decision makers at zonal, regional and federal authorities if the remaining land resources of the park are to be conserved and used in an integrated and sustainable manner.

\section{References}

[1] Haile, K., Sandewall, M. and Urgessa, K. (2009) Wood Fuel Demand and Sustainability of Supply in South-Western Ethiopia, Case of Jimma Town. Research Journal of Forestry, 3, 29-42.

[2] Teka, M. (2006) Energy Policy of Ethiopia. Ministry of Mines and Energy, Geothermal Energy Conference, Addis Ababa.

[3] Amare, D., Endeblhatu, A. and Muhabaw, A. (2015) Enhancing Biomass Energy Efficiency in Rural Households of Ethiopia. Journal of Energy and Natural Resources, 4, 27-33.

[4] Asfaw, A. and Demissie, Y. (2012) Sustainable Household Energy for Addis Ababa, Ethiopia. The Journal of Sustainable Development, 8, 1-11.

[5] Ighobor, K. (2014) Light at the End of the Tunnel. Africa Renewal. http://www.un.org/africarenewal/magazine/april-2014/light-end-tunnel

[6] CIA (Central Intelligence Authority) (2016) The World Fact Book. https://www.cia.gov/library/publications/the-world-factbook/geos/et.html

[7] EFAP (1994) Ethiopian Forestry Action Program, EFAP. Addis Abeba.

[8] IUCN (1990) Ethiopia National Conservation Strategy. Vol. 1. Addis Abeba.

[9] Gebrehiwot, K. (2003) Ecology and Management of Boswellia papyrifera (Del.) Hochst. Dry Forests in Tigray, Northern Ethiopia. Doctoral Dissertation submitted for the Degree of Doctor of Forest Sciences of the Faculty of Forest Sciences and Forest Ecology GeorgAugust-University of Göttingen, Göttingen.

[10] EARO (2000) Forestry Research Strategic Plan. Ethiopian Agricultural Research Organiza- 
tion.

[11] Gebrehiwot, K. (1995) Scope for Enhancing Farm Productivity through Improved Traditional Agroforestry Practices Using Native Species of Trees in Tigray, Northern Ethiopia. M.Sc. Dissertation, University College of North Wales, Bangor.

[12] Jacobs, M.J. and Schloeder, C.A. (2001) Impacts of Conflict on Biodiversity and Protected Areas in Ethiopia. Biodiversity Support Program, Washington DC.

[13] EFDRE (Embassy of the Federal Democratic Republic of Ethiopia) (2015) Tourism, National Parks. http://www.Ethiopia-emb.or.jp/tourism_e/park/index.html\#04

[14] EWCA (Ethiopian Wildlife Conservation Authority) (2015) Location Map of Nech Sar National Park, Addis Ababa, Ethiopia.

[15] Desse, A.M. (2015) Summary of Attractions, Challenges, Research, Management and Partnership Issues on Nech Sar National Park. Arba Minch, Ethiopia.

Submit or recommend next manuscript to SCIRP and we will provide best service for you:

Accepting pre-submission inquiries through Email, Facebook, LinkedIn, Twitter, etc.

A wide selection of journals (inclusive of 9 subjects, more than 200 journals)

Providing 24-hour high-quality service

User-friendly online submission system

Fair and swift peer-review system

Efficient typesetting and proofreading procedure

Display of the result of downloads and visits, as well as the number of cited articles

Maximum dissemination of your research work

Submit your manuscript at: http://papersubmission.scirp.org/ 